\title{
Nordic
}

Research

$$
\text { - Key Data }
$$

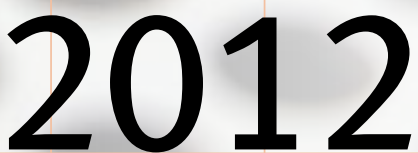



Nordic Research
- Key Data 2012

ANP 2012:731 


\section{Nordic Research - Key Data 2012}

ISBN 978-92-893-2358-1

DOI http://dx.doi.org/10.6027/ANP2012-731

ANP 2012:731

(C) Nordic Council of Ministers

Layout: Jette Koefoed

Fotos: ImageSelect, Ojo foto

Print: Scanprint, Viby

Oplag: 1000

Printed in Denmark

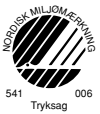

\section{Nordic Council of Ministers}

Ved Stranden 18

DK-1061 Copenhagen $\mathrm{K}$

Telefon: +4533960200

www.norden.org

\section{Nordic co-operation}

Nordic co-operation is one of the world's most extensive forms of regional collaboration, involving Denmark, Finland, Iceland, Norway, Sweden, and the Faroe Islands, Greenland, and Åland.

Nordic co-operation has firm traditions in politics, the economy, and culture. It plays an important role in European and international collaboration, and aims at creating a strong Nordic community in a strong Europe.

Nordic co-operation seeks to safeguard Nordic and regional interests and principles in the global community. Common Nordic values help the region solidify its position as one of the world's most innovative and competitive. 


\section{Content}

Introduction

Who prepares the R\&D statistics?

How are R\&D statistics compiled?

Basic definitions of Research and experimental development (R\&D)

Data sources

Symbols and country codes

Abbreviations

Key to the tables

Highlights

Statistics 



\section{Introduction}

This is the first version of this booklet, "Nordic research - Key data 2012", containing tables and figures on Nordic R\&D statistics and science and technology indicators. It is created by the Nordic Institute for Studies in Innovation, Research and Education (NIFU) and published by the Nordic Council of Ministers.

The booklet together with all statistical material is also available electronically at www.norden.org/publications

\section{Who prepares the R\&D statistics?}

In the Nordic countries the statistical surveys on resources devoted to R\&D are carried out by the National Statistical offices for Denmark, Sweden and Finland. In Iceland RANNIS (the Icelandic Research Council) carry out the survey. In Norway, the preparation of R\&D statistics is carried out by Statistics Norway (the business enterprise sector) and NIFU (government sector, higher education sector). Links to the national producers of R\&D statistics are listed in the electronic version of this booklet at www.norden.org/publications

\section{How are R\&D statistics compiled?}

The OECD have prepared international guidelines for R\&D statistics in the "Frascati Manual" (The Measurement of Scientific and Technological Activities: Proposed Standard Practice for Surveys on Research and Experimental Development "Frascati Manual 2002", OECD 2002). Nordic R\&D statistics are based on information from administrative registers and questionnaires sent to the R\&D performing units in each sector. 


\section{Basic definitions of Research and experimental development}

(R\&D)

Research and experimental development (R\&D) comprises creative work undertaken on a systematic basis in order to increase the stock of knowledge, including knowledge of man, culture and society, and the use of this stock of knowledge to devise new applications. Three types of R\&D may be distinguished: Basic research, applied research and experimental development.

\section{Data sources}

International R\&D statistics are extracted from the OECD's Main Science and Technology Indicators 2011-2 supplemented with national sources. The data source for educational level is Education at a Glance 2011, OECD. Information about doctoral students and awarded doctoral degrees in the Nordic and Baltic countries are taken from the NORBAL database, operated by NIFU. Bibliometric data are extracted from the National Science Indicators database, prepared by Thomson Scientific in the U.S. This database contains global publication and citation statistics. Data on patents are from the OECD. 
Symbols and country codes COUNTRY CODES COLOURS

Denmark DK

Estonia EE

Finland $\mathrm{FI}$

Iceland IS

Latvia

LV

Lithuania LT

Norway NO

Sweden SE

Green

Purple

Grey

Red

Yellow
Key to the tables

.. Data not available

Dark grey : Data may not be made public

Blue $\quad-0$

Light grey

\section{Abbreviations}

GDP

Gross national product

EPO

The European Patent Office

EU-27

The present $27 \mathrm{EU}$ members

$R \& D$

Research and experimental development

GBAORD Government budget appropriations or outlays for R\&D

ISCED International Standard Classification of Education

OECD Organisation for Economic Co-operation and Development

PPP\$ Purchasing power parity. A conversion to a common unit (US\$) to enable comparisons of R\&D between countries as to currency and purchasing power.

PNP sector Private non-profit sector

All expenditures are given in current prices, unless otherwise indicated. In 20111.00 PPP US $\$=9.62$ NOK (Main Science and Technology Indicators 2011-2, OECD). 



\section{Highlights}

- Total R\&D expenditure in the Nordic countries amounted to 32 billion PPP\$ or approximately 290 billion NOK in 2010.

- Sweden accounted for 39 per cent of total Nordic R\&D expenditure, Finland 24 per cent, Denmark 21 per cent, Norway 15 per cent and Iceland 1 per cent.

- From 2001 to 2010 there was an average annual real growth in the Nordic countries' R\&D expenditure of 4.5 per cent. Denmark and Norway saw the strongest growth, followed by Finland, Iceland and Sweden.

- R\&D expenditure per capita was highest in Finland in 2010, at 1415 PPP \$, followed by Sweden, Denmark and Iceland. Norway spent least per capita among the Nordic countries, at 970 PPP\$. However, all of the Nordic countries are ahead of the EU-27 and OECD on this measure, at roughly 600 and 800 PPP\$ per capita, respectively.

- Norway had the highest proportion of R\&D expenditure financed by public sources in 2009, while Finland had the highest proportion of private sector financing. Funding from other domestic sources was between 1 and 3 per cent in the Nordic countries and funding from foreign sources between 7 and 10 per cent.

- 2010 figures for R\&D expenditure as a share of GDP show Finland with 3.9 per cent, Sweden on 3.4 per cent, Denmark on 3.2 per cent, Iceland on 3.1 per cent and Norway with 1.7 per cent. In the EU-27 and OECD the equivalent figures for 2009 were 1.9 and 2.4 per cent respectively.

- When R\&D activity over various performing sectors is considered, the business enterprise sector is shown to account for about 70 per cent of R\&D expenditures in Finland, Sweden and Denmark. This is in line with OECD figures. In Iceland and Norway, the level 
was just over 50 per cent and in the EU-27 it is around 60 per cent.

- When government R\&D allocations (GBAORD) are converted to PPP\$, this reveals an increase from 2010 to 2011, of 5 per cent in Denmark, while a decline of around 3 per cent is apparent in Finland and Norway, and a decline of almost 1 per cent is shown in Sweden.

- As of 2010, the proportion of the population with higher education varied from 33 per cent in Iceland to 37 per cent in Finland and Norway. The OECD average proportion was 30 per cent.

- Finland had the highest proportion of higher-educated women in the population, at 43 per cent.

- The number of PhDs per million inhabitants is around twice as high in the Nordic countries as in the Baltics (in 2010). Finland leads with 326 PhDs per million inhabitants, while Norway has the lowest score in the Nordic region, at 242.

- In Sweden, there has been a decline in the number of doctoral degrees awarded each year since 2008.

- The percentage of PhDs awarded to women in Nordic countries in 2010 was highest in Finland ( 53 per cent) and lowest in Denmark and Iceland (both with 45 per cent).

- Sweden has a particularly high proportion of PhDs awarded in medicine (38 per cent), while Denmark and Latvia have the highest proportions in technology (both 23 per cent). Among the Nordic countries, Finland had the highest proportion of PhDs awarded within the humanities and social sciences (34 per cent).

- In 2010, the proportion of female researchers was highest in Iceland ( 42 per cent) and lowest in Finland ( 31 per cent). The proportion of female professors was highest in Iceland (27 per cent) and lowest in Denmark (17 per cent).

- The percentage of R\&D personnel (full-time-equivalents, FTE) 
in the business enterprise sector was highest in Sweden and lowest in Norway. The proportion of R\&D FTE in the higher education sector was approximately $1 / 3$ of total R\&D FTE in all Nordic countries, except Sweden, where they accounted for $1 / 4$.

- The number of scientific articles per 1000 inhabitants ranged from 2.4 in Iceland to 1.9 in Finland and Norway.

- Growth in the number of scientific articles produced in the period 2006-2010 was highest in Iceland, followed by Norway, Denmark, Sweden and Finland.

- From 2009 to 2010, the trend in the number of scientific articles has been positive for Iceland and Denmark, while Sweden and Norway showed little growth, and there was a decline in Finland.

- In recent years, Danish articles were most cited among the Nordic countries, followed by those from Sweden, Norway and Finland.

- Icelandic scientists have the highest proportion of international co-authored articles in the Nordic countries, and the highest percentage of these articles written with researchers from other Nordic countries (33 per cent). Sweden had the lowest proportion (14 per cent) of international co-authored articles with other Nordic countries.

- Nordic researchers are more likely to have co-authored articles with researchers in non-Nordic EU-27 countries (47 per cent of all Nordic, co-authored papers) than with other Nordic researchers (at 16 per cent).

- The propensity to patent in the Nordic countries was highest in Sweden in the last decade (among selected countries, only Germany and Switzerland were more active), followed by Finland and Denmark, Norway and Iceland. 


\section{Expenditure}

R\&D expenditure in the Nordic countries (Mill. PPPS). 2010.

\begin{tabular}{lrrrrrrrr}
\hline Country/region & DK & Fl & IS & NO & SE & Nordic & OECD $^{1}$ & EU 27 \\
\hline Mill. PPP\$ & 6816 & 7589 & 356 & 4742 & 12536 & 32039 & 968108 & 304891 \\
\hline
\end{tabular}

${ }^{1} 2009$.

Sources: National sources, MSTI, 2011-2

R\&D expenditure in the Nordic countries (Mill. PPPS). 2010.

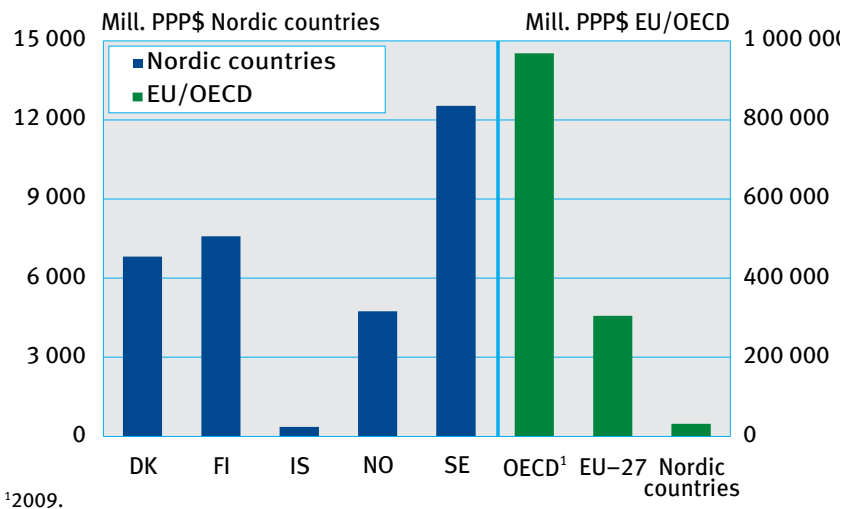

Sources: National sources, MSTI 2011-2

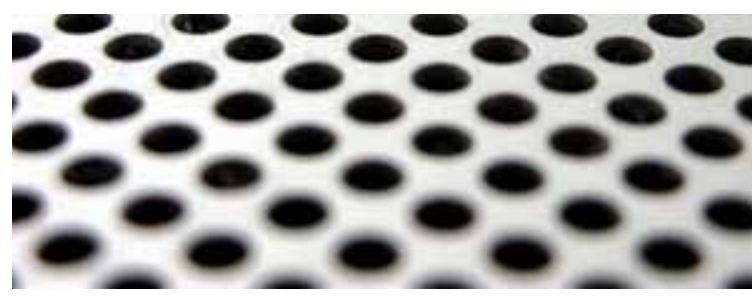


$R \& D$ expenditure in total and per capita by country (current PPPS).

\begin{tabular}{lrrrrrrr}
\hline & DK & FI & IS & NO & SE & OECD $^{1}$ & EU 27 \\
\hline $\begin{array}{l}\text { R\&D exp. per } \\
\text { capita }\end{array}$ & 1229 & 1415 & 1123 & 970 & 1337 & 790 & 608 \\
$\begin{array}{l}\text { R\&D expen- } \\
\text { diture }\end{array}$ & 6816 & 7589 & 356 & 4742 & 12536 & 968108 & 304891 \\
\hline $\begin{array}{l}{ }^{12009 .} \\
\text { Sources: National sources, MSTI, 2011-2 }\end{array}$ & & & & &
\end{tabular}

R\&D expenditure in the Nordic countries (Mill. PPPS). 1981-2011.

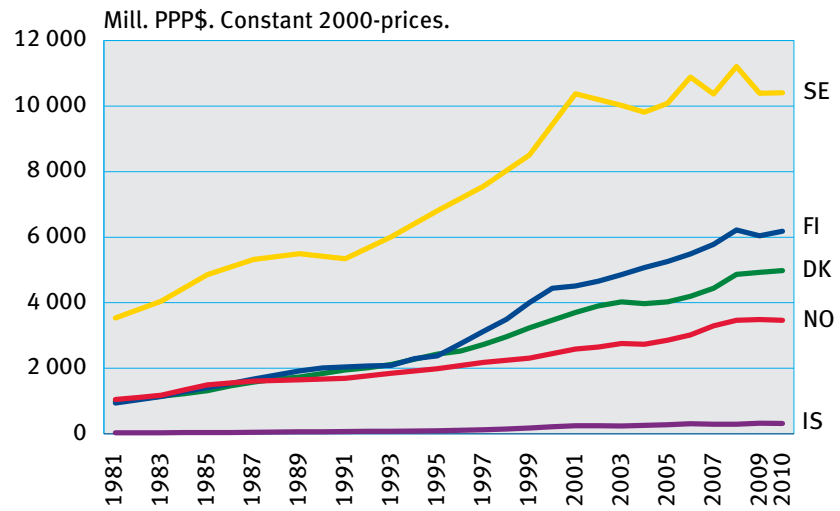

Sources: National sources, MSTI 2011-2 


\section{Expenditure}

$R \& D$ expenditure in the Nordic countries, EU and OECD, as a share of GDP and per capita. 2010.

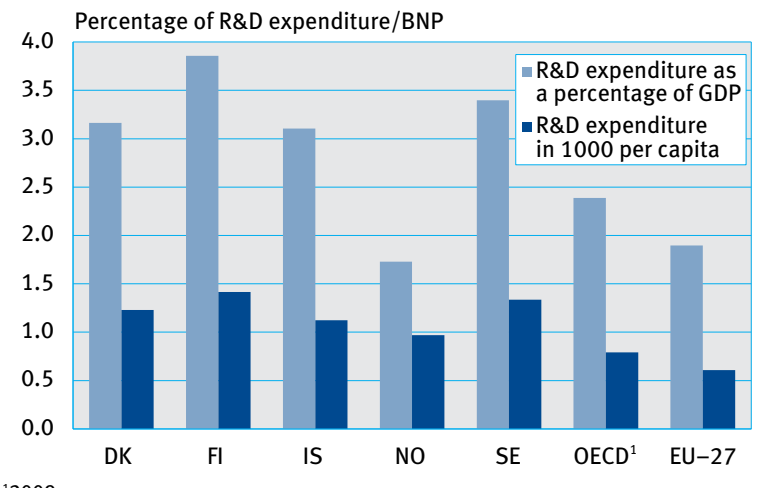

${ }^{1} 2009$.

Sources: National sources, MSTI 2011-2

$R \& D$ expenditure by country and performing sector (business enterprise sector, government sector, higher education sector and PNP-sector), per cent. 2010.

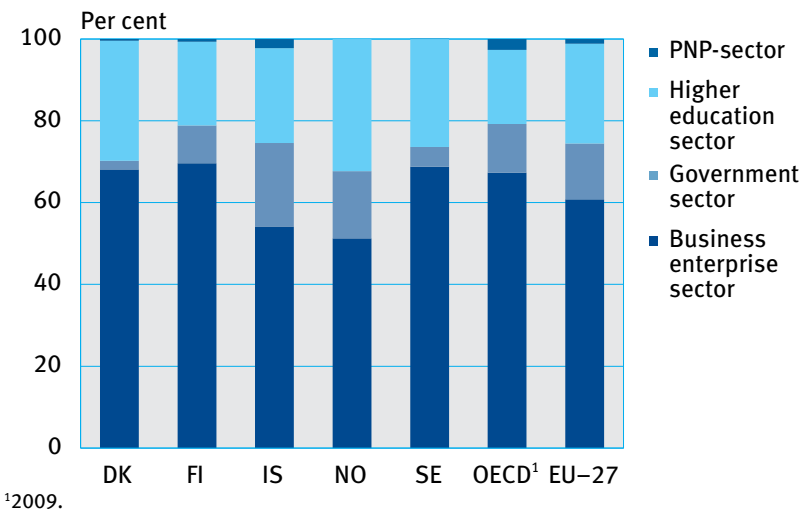

Sources: National sources, MSTI 2011-2 
R\&D expenditure by country and source of funds. 2010.

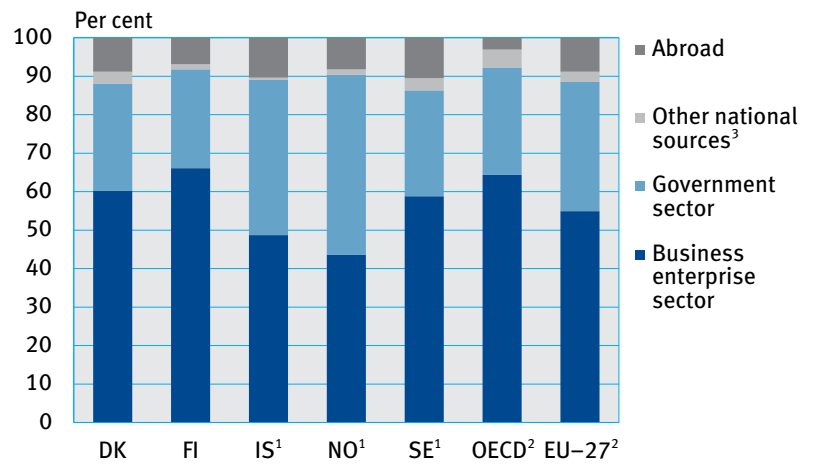

${ }^{1} 2009$

${ }^{1} 2008$

${ }^{3}$ Higher education sector and PNP-sector.

Sources: National sources, MSTI 2011-2

Government budget appropriations and outlays for $R \& D$ (GBAORD) as a percentage of GDP. 1981-2011.

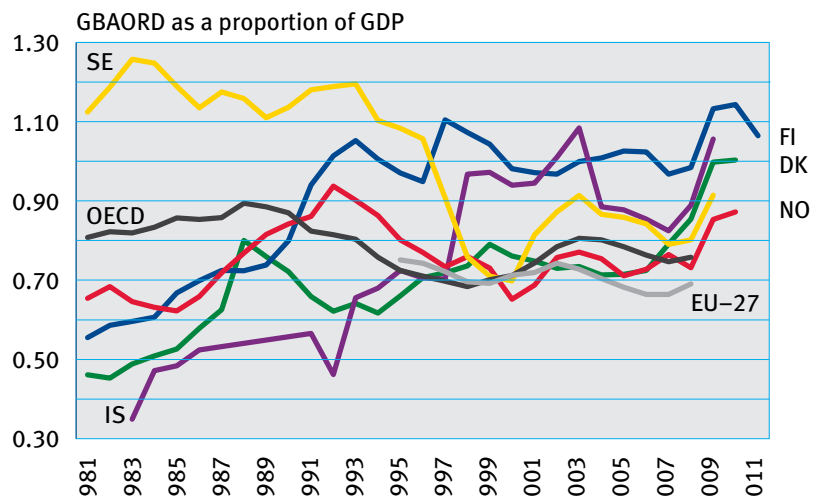

Sources: MSTI 2011-2

Nordic Research - Key Data 2012 
Higher education

Percentage of the population with higher education in 2009.

\begin{tabular}{lrrrrrrr}
\hline & DK & FI & IS & NO & SE & EU & OECD \\
\hline Men & 31 & 31 & 29 & 32 & 28 & 25 & 29 \\
Women & 38 & 43 & 37 & 41 & 38 & 29 & 31 \\
Total & 34 & 37 & 33 & 37 & 33 & 27 & 30 \\
\hline
\end{tabular}

${ }^{1}$ ISCED level 5 and 6.

Kilde: OECD Education at a Glance 2011

Percentage of the population with higher education in 2009.

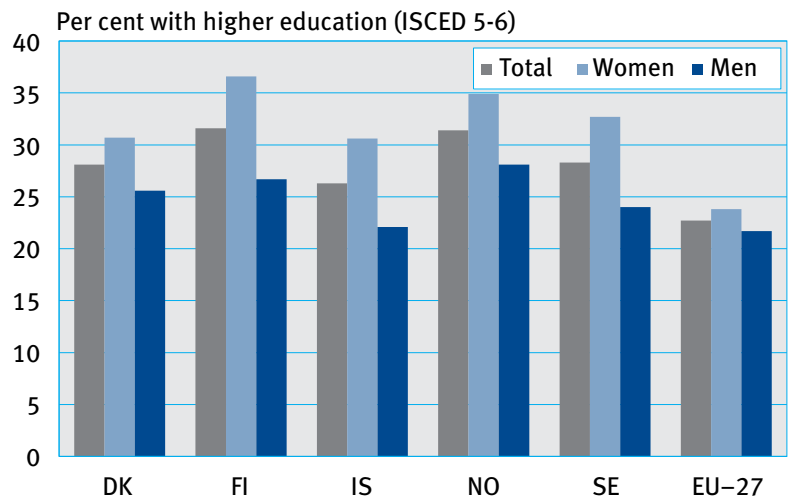

Source: Eurostat

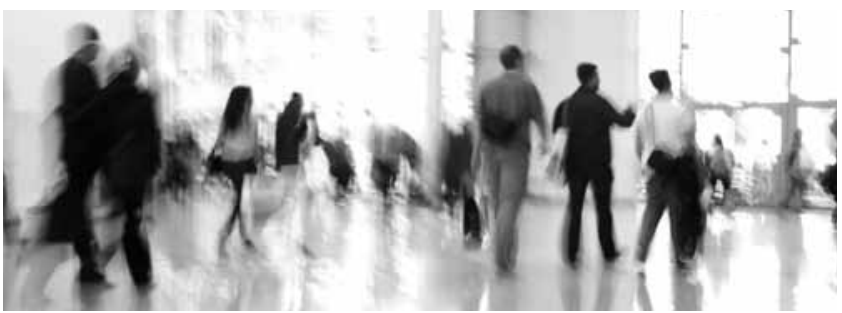




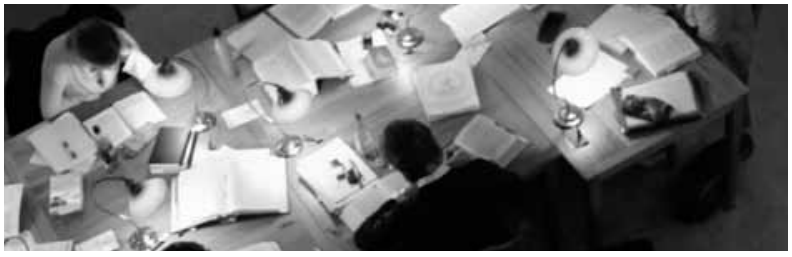

Graduates in first and second stage of tertiary education (ISCED 5-6) in the Nordic countries by field of science. 2009.

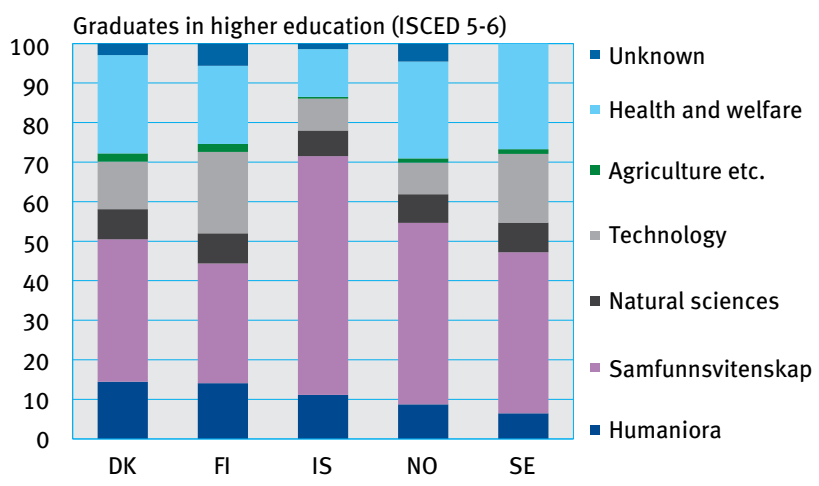

Source: Eurostat

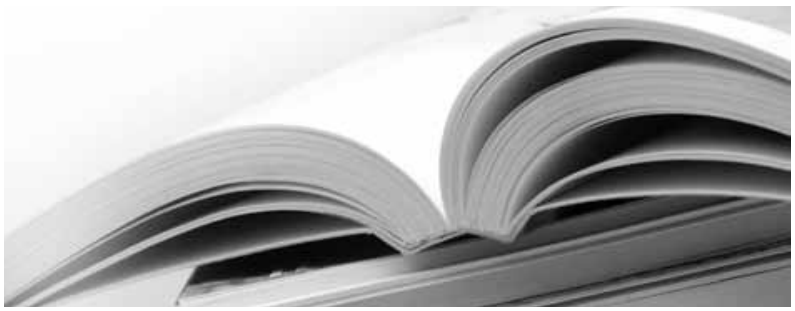




\section{Doctoral degrees}

Number of Ph.D. students by country (the Nordic and Baltic countries) and field of science. 2010.

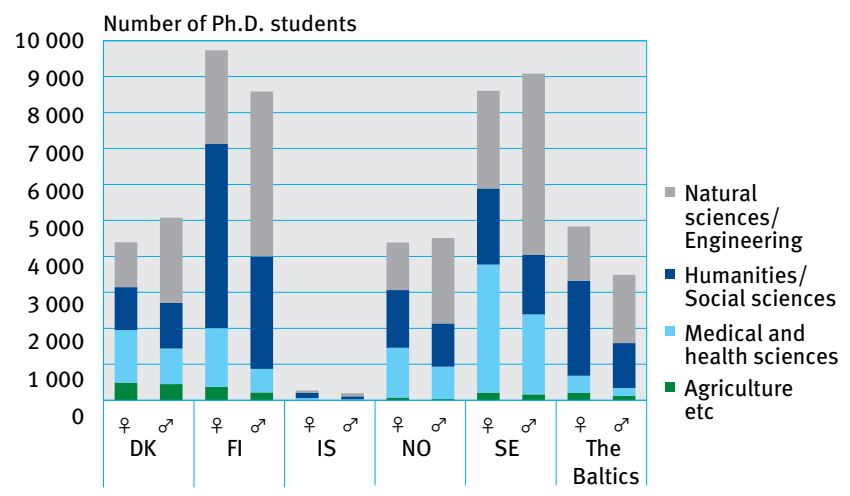

Source: NORBAL

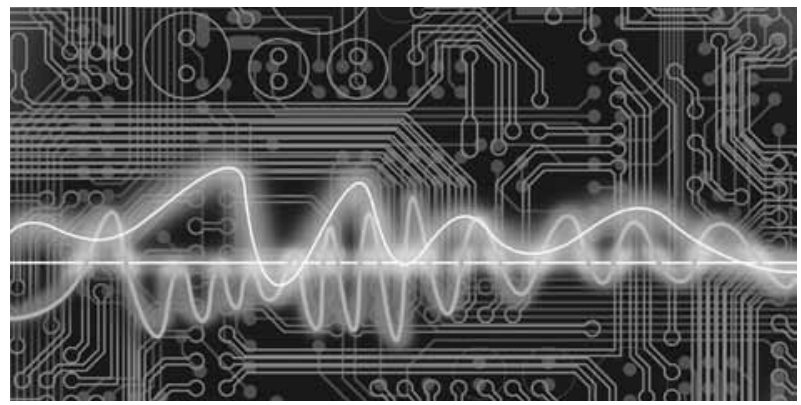


Number of awarded doctoral degrees by country (the Nordic and Baltic countries). 1990-2010.

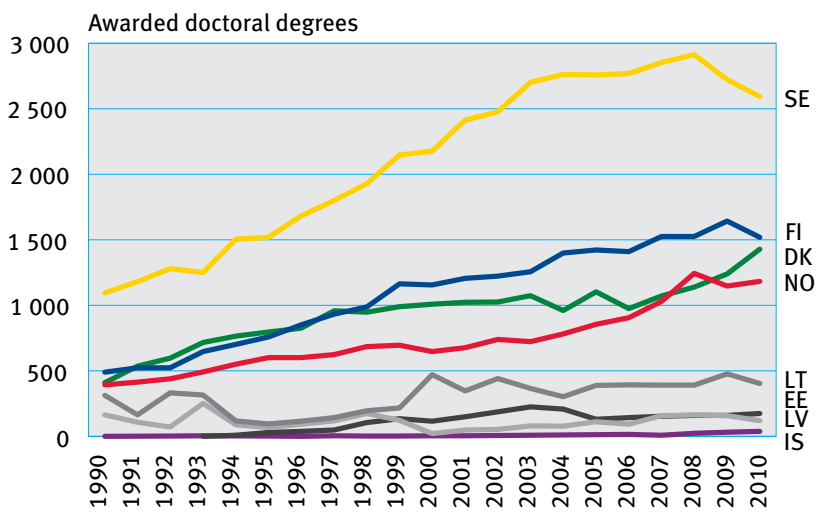

Source: NORBAL

Awarded doctoral degrees per mill. capita by country. 1990-2010.

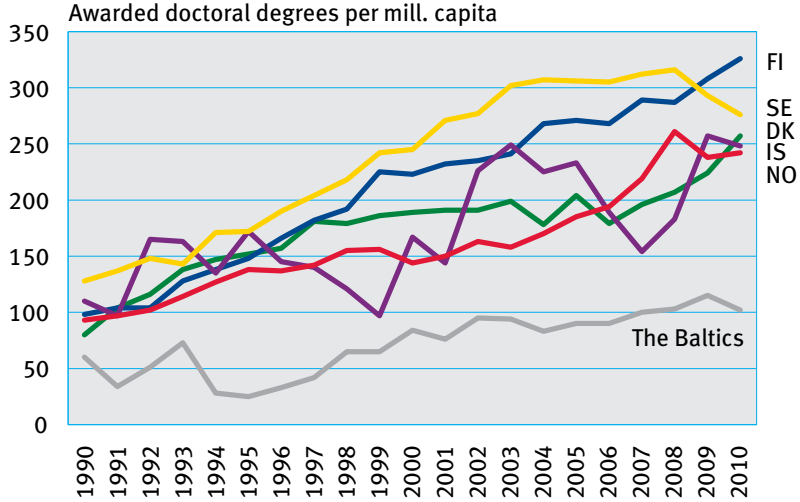

Source: NORBAL 


\section{Doctoral degrees}

Awarded doctoral degrees by country (the Nordic and Baltic countries) and field of science. Per cent. 2010.

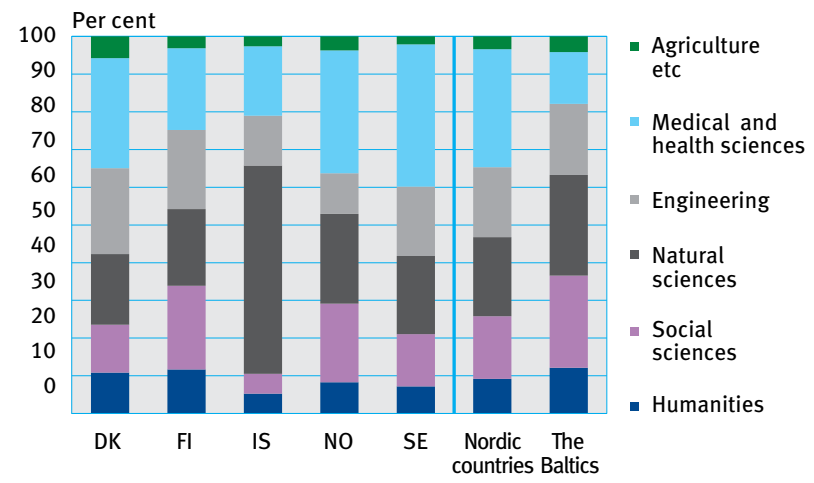

Source: NORBAL

Awarded doctoral degrees by gender and country. 2000 og 2010.

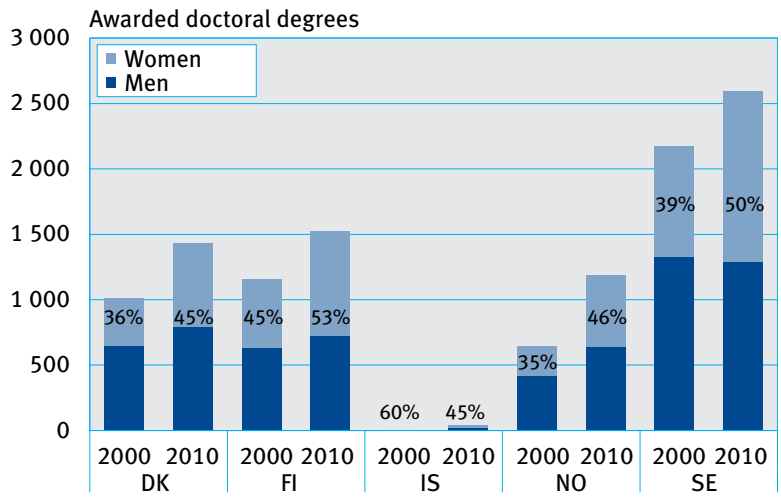

Source: NORBAL 
Researchers in the Nordic countries by gender and country. Number and per cent. 2009.

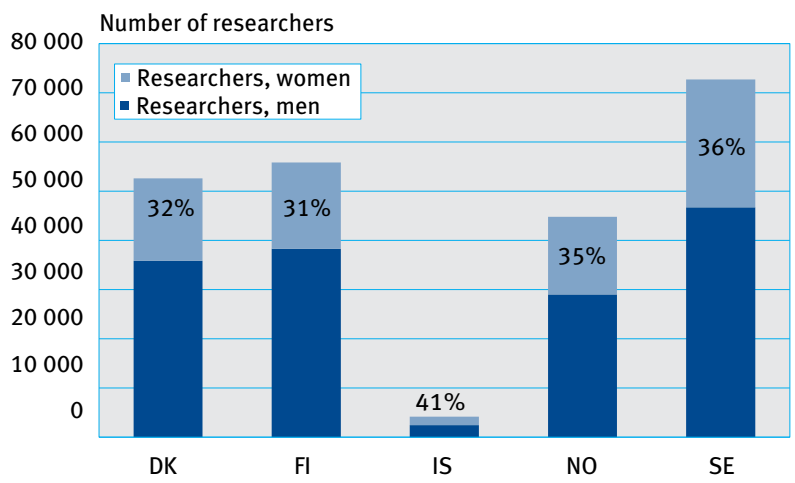

Source: MSTI, 2011-2

Professors within academia (grade A) by gender and country. Per cent. 2010.

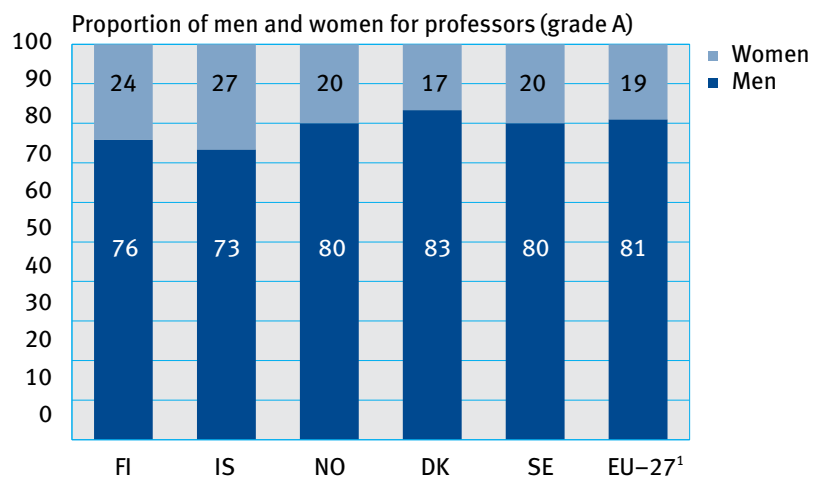

${ }^{1} 2007$

Source: National contributors to Eurostat She Figures, She figures 2009 


\section{Researchers}

$R \& D$ full time equivalents (FTE) by sector of performance and country. Per cent. 2010.

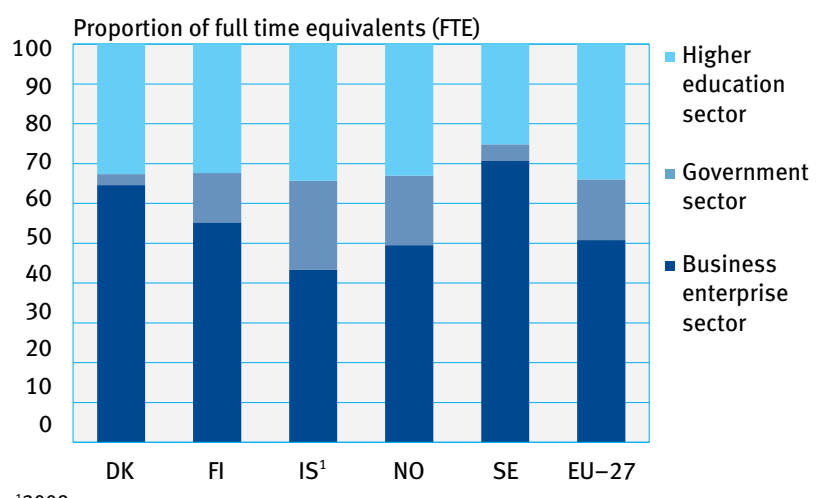

${ }^{1} 2009$.

Sources: National sources, MSTI, 2011-2

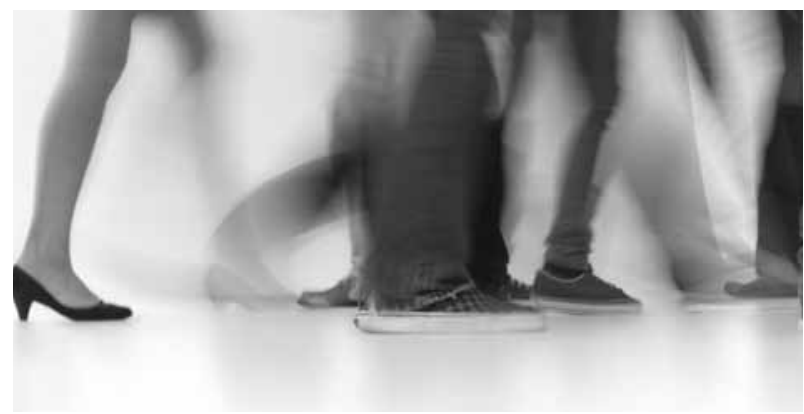


Scientific publishing per mill. capita in the Nordic countries.

1981-2010.

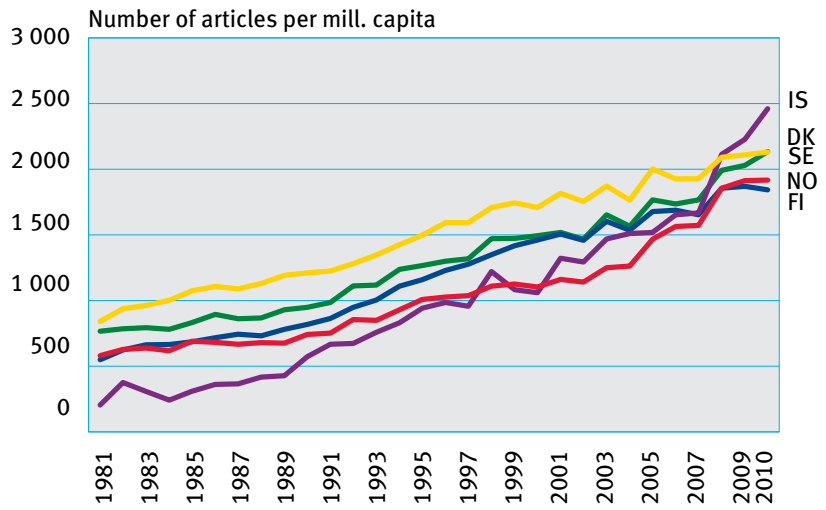

Sources: National Science Indicators/Thomson Reuters/NIFU

Scientific publishing per 1000 capita in the nordic countries in 2010 and average annual change 2006-2010. Number and per cent.

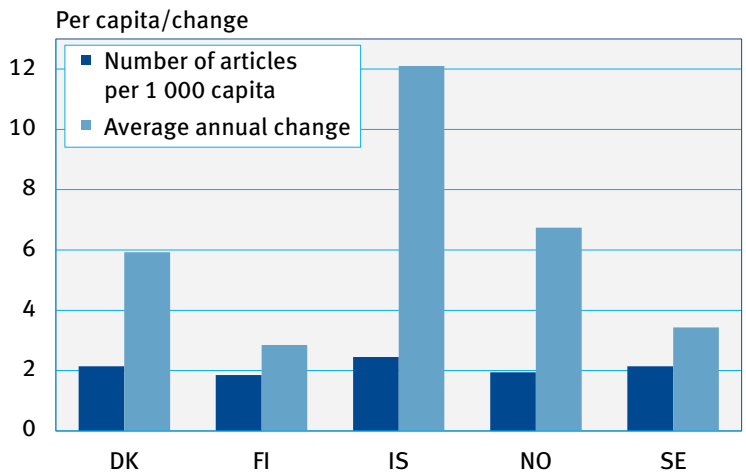

Sources: National Science Indicators/Thomson Reuters/NIFU 
Scientific publishing in the nordic countries. Number of articles. 1981-2010.

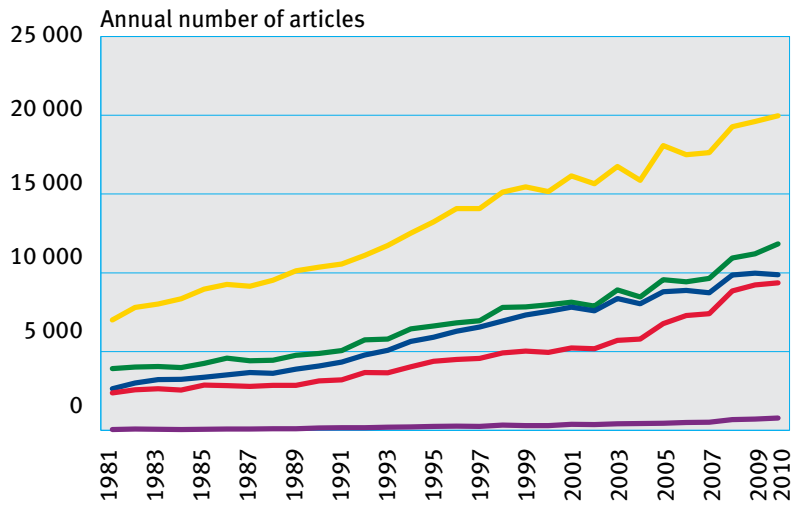

Sources: National Science Indicators/Thomson Reuters/NIFU

Relative index of citation for published articles in international journals for four Nordic countries. 1981-2009.

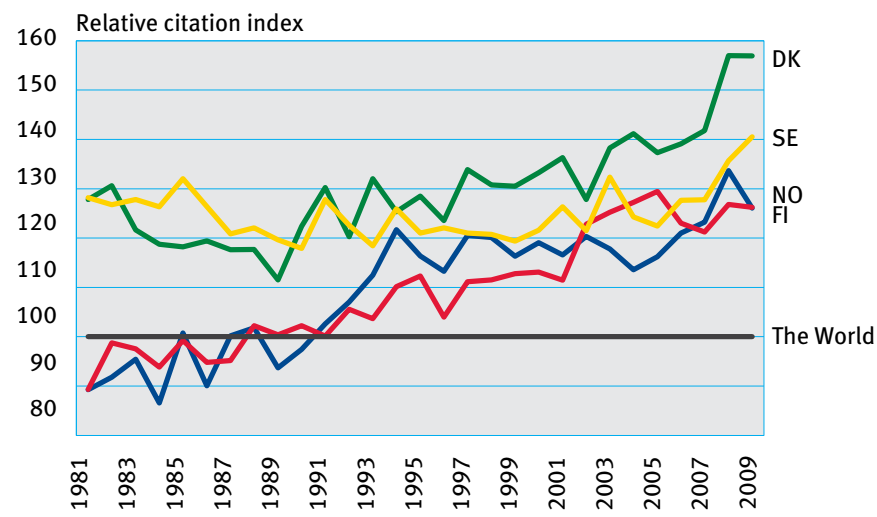

Kilde: National Science Indicators/Thomson Reuters/NIFU 
The share of Nordic co-publication as a percentage of all co-publications for each Nordic country. Per cent. 1984-2008.

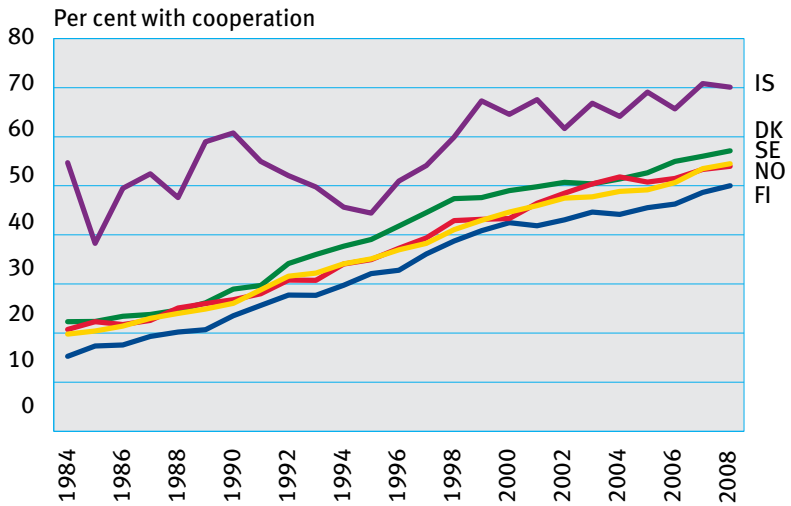

Source: Nordforsk (2010) International research cooperation in the Nordic countries. A publication from the NORIA-NET

Co-publication with other Nordic countries for each Nordic country. Share of international co-publication by country. 1984-2008.

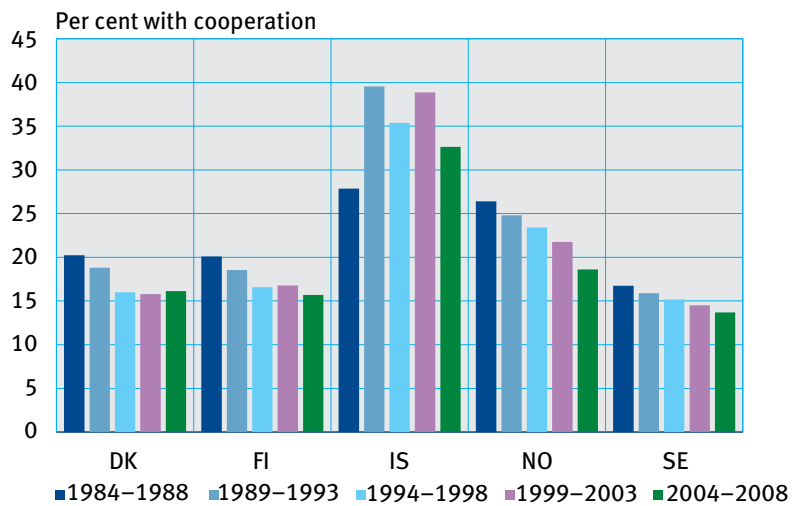

Source: Nordforsk (2010) International research cooperation in the Nordic countries. A publication from the NORIA-NET 
Inter-regional co-operation between Nordic countries and other regions in the world. Share of the Nordic countries publications with international co-operation. 2004-2008.

\begin{tabular}{lr}
\hline Country & Per cent \\
\hline Asia & $5 \%$ \\
South and central America & $2 \%$ \\
Other world & $7 \%$ \\
North-America & $17 \%$ \\
Other Europe & $3 \%$ \\
EU27, excl. Nordic countries & $47 \%$ \\
Nordic countries & $16 \%$ \\
\hline
\end{tabular}

Source: Nordforsk (2010) International research cooperation in the Nordic countries. A publication from the NORIA-NET

Inter-regional co-operation between Nordic countries and other regions in the world. Share of the Nordic countries publications with international co-operation. 2004-2008.

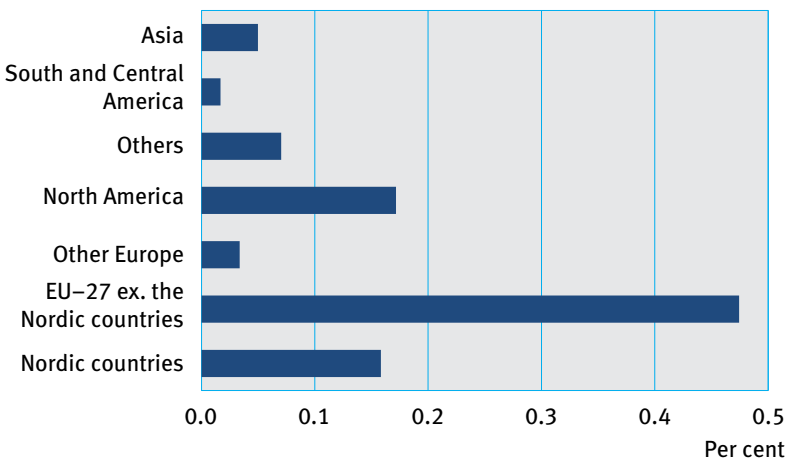

Source: Nordforsk (2010) International research cooperation in the Nordic countries. A publication from the NORIA-NET 
Propensity to patent ${ }^{1}$ in the Nordic countries. Number of patents per 1000 workers. 1999-2008.

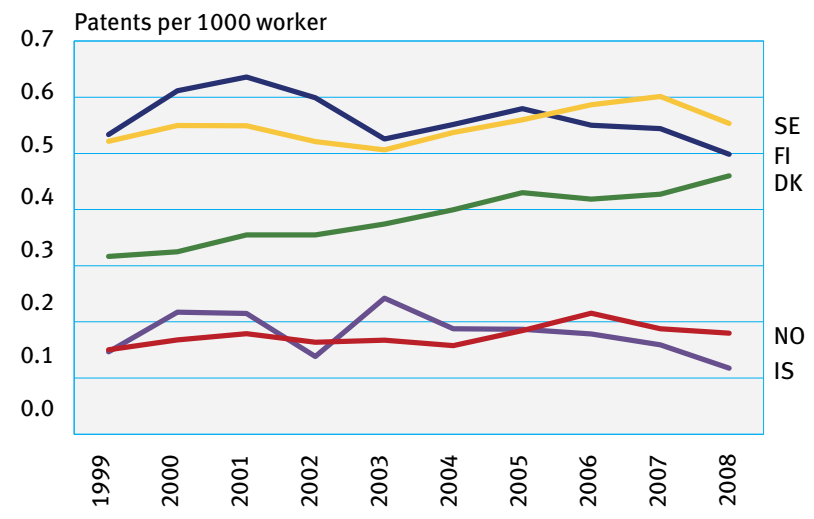

Source: OECD Statsextracts 22 jan 2012 year.

Propensity to patent ${ }^{1}$ for selected countries. Number of patents per 1000 workers. 2008.

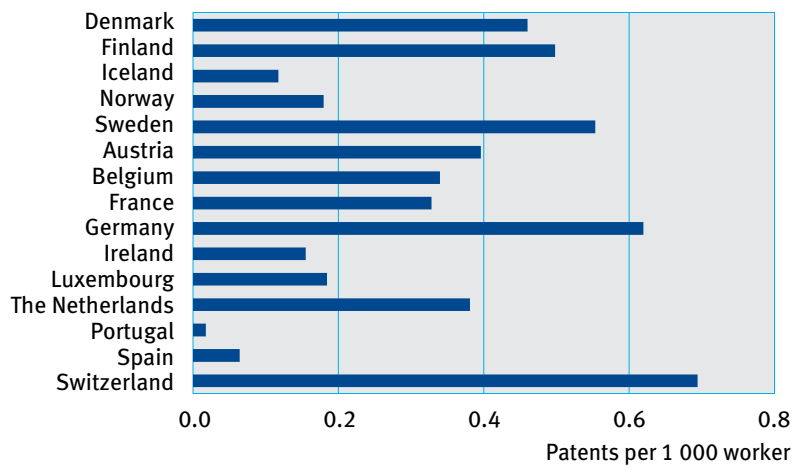

${ }^{1}$ Propensity to patent is measured by the number of applications per 1000 in the workforce (civil). This applies to patent applications, provided the European Patent Office (EPO) by application Source: OECD Statsextracts 22 jan 2012 year. 




\section{norden}

\section{Nordic Council of Ministers}

Ved Stranden 18

DK-1061 Copenhagen K

www.norden.org

ISBN 978-92-893-2358-1

DOI http://dx.doi.org/10.627/ANP2012-731 ANP 2012:731 